\title{
Pięć punktów w widmowych wierszach Ryszarda Krynickiego
}

\author{
Iwona Misiak
}

TEKSTY DRUGIE 2016, NR 2, S. 272-293

DOI: 10.18318/td.2016.2.14

$\mathbf{W}$ utworach Ryszarda Krynickiego odnajduję pięć punctum ${ }^{1}$, które świadczą o widmowości jego poezji: drzwi łączące byt/niebyt, paradoksalność „śmiercionośnego życia i życiodajnej śmierci"2, nietrwały stan wierszy/nie-wierszy, heterogeniczny podmiot i jego wymowne milczenie oraz przełamywanie stylu. Punkty te wyznaczają główne kierunki moich przemyśleń dotyczących nakłuwania przestrzeni, rozdzierania czasu i powstawania otworów, przez które przechodzą „nieśmiertelne/niewidome/widma”.

1 Zob. R. Barthes Światło obrazu. Uwagi o fotografii, przeł. J. Trznadel, Wydawnictwo KR, Warszawa 1996, s. 47. Barthes pisał o "współistnieniu dwu nieciągłych elementów, różnych i nie należących do tego samego świata" (tamże, s. 41): punctum - szczególe, który nakłuwa, studium - kulturowym polu odniesienia. Dziękuję M. Rudaś-Grodzkiej za jej inspirujące uwagi o punctum.

2 R. Krynicki Pęd pogoni, pęd ucieczki, w: tegoż Pęd pogoni, pęd ucieczki, Zrzeszenie Studentów Polskich, Warszawa-Poznań 1968, s. 35.

3 R. Krynicki Z Maxa Hölzera, w: tegoż Wiersze wybrane, Wydawnictwo a5, Kraków 2009, s. 23. Paginacje w tekście odnoszą się do tego wydania, z wyjątkiem przytoczeń pochodzących z wcześniejszych tomów Krynickiego.
Iwona Misiak - dr historyczka literatury, współpracuje z Uniwersytetem Kardynała Stefana Wyszyńskiego, redaktorka kwartalnika „Fraza". Zainteresowania badawcze: literatura polska XX iXXI wieku. Ostatnio opublikowała Poczqtekzagadki. O labiryntowej twórczości Ryszarda Krynickiego (2016). Kontakt: iwona_misiak@op.pl 
W tych zagadkowych miejscach pojawia się podmiot, którego status jest nieokreślony: jest i nie jest, podobnie jak zjawy. Jego nieuchwytna obecność jest usprawiedliwiona - bohater wierszy Krynickiego bezustannie przemieszcza się w przestrzeni między bytem a niebytem. Poezja zatem nie ma stałego centrum i niezmiennych granic, teksty istnieją niepewnie również dlatego, że są ciągle przekształcane. Uznaję, że powtarzające się przełamywanie stylu w poezji Krynickiego jest dematerializacją ciała liryki, aktem niszczenia „ja”, aby mogło zaistnieć nowe. Omawiając ten proces, uwzględniam zjawianie się i znikanie widmowych przybyszów.

Zastanawiam się nad spektralnym wymiarem milczenia, które bywa reakcją na widok widm. Staram się rozszyfrować znaczenie sekretnych słów, których rdzeniami są resztki słów zmarłych, uznając, że matką/ojcem wielu wierszy Krynickiego są fantomy, zarówno anonimowe, jak i przybierające imiona. W wyniku abiektalnego płodzenia słów ze zmarłymi, a potem rodzenia nowych teksty noszą znamiona widmowości. Metryka poezji Krynickiego jest tajemnicza, dlatego ważnym zadaniem będzie wyznaczenie orientacyjnych punktów na granicy życia i śmierci, ponieważ tam otwiera się perspektywa umożliwiająca analizę wierszy/nie-wierszy, w których czas i przestrzeń, podmiot i język ulegają rozerwaniu.

Pierwszy punkt, na który trafiłam, znajduje się w utworze Czasami wierzę, zamieszczonym w tomie Organizm zbiorowy. Tutaj drzwi stanowią swoiste punctum w zamkniętym pokoju - ten punkt wnika w przestrzeń, która przeistacza się w nieograniczone pole interakcji zjaw i podmiotu.

\section{Drzwi i widma}

Stanisław Barańczak w szkicu Nie podlegać nicości (1978) podkreślił, że bohater wierszy Krynickiego jest „obdarzony osobliwą podwójnością widzenia”, mianowicie postrzega swoją rzeczywistość z perspektywy uczestnika i przybysza. Jako uczestnik nie separuje się od innych ludzi, a przyjmując optykę przybysza, ze zdziwieniem dostrzega „nieludzkość ludzkiego świata”, i jest to istotą konfliktu obu stanowisk „w obrębie jednej świadomości bohatera"6. Barańczak zauważył, że w utworach poety „często powraca [...] motyw

\footnotetext{
4 S. Barańczak Nie podlegać nicości, w: tegoż Etyka i poetyka, Znak, Kraków 2009, s. 320.

5 Tamże, s. 324.

6 Tamże.
} 
«przybyszów z innego świata»" . Dla nich normalność życia w totalitarnie zorganizowanym społeczeństwie jest czystym szaleństwem ${ }^{8}$.

W wielu wierszach Krynickiego, również w Czasami wierzę, ujawnia się jeszcze coś, co jest „nienormalne” i mieści się w rysie podwójnej świadomości podmiotu oraz w miejscu między życiem a śmiercią:

Powiem prawdę: czasami wierzę

w istnienie tamtego świata, wierzę w zjawy,

wampiry, wysysające mózgi i krew,

zresztą, może bardziej się boję niż wierzę

(co na jedno wychodzi w naszych czasach: bać się - wierzyć).

Staram się wtedy nie siadać plecami do drzwi,

drzwi żyją własnym życiem [...].9

W Czasami wierzę drzwi pozostają zamknięte, choć jest oczywiste, że „prędzej czy później się otworzą", mężczyzna wie, że dotknie go „lodowata ręka” lub zaciśnie się na jego sercu: „powiem prawdę: nie wierzę, aby to była ręka / poety, który, niezależnie od ludzkiej / czy nieludzkiej śmierci, jaka go spotkała, // ciągle jeszcze mówi do nas swoimi żywymi słowami"10. W późniejszej wersji utworu widmo bezimiennego poety rozszczepia się: zjawiają się Osip Mandelsztam i Georg Trakl (czy dlatego, że Krynicki tłumaczył Trakla, a Barańczak, któremu zadedykował ten wiersz - Mandelsztama?).W nowym wariancie tytuł Czasami wierzę został skrócony do Wierzę i przypomina credo, nieco ironiczne, gdyż pozbawione religijnej konotacji.

Bohater wiersza wpatruje się w drzwi, które mają się otworzyć, niekiedy odwraca się do nich plecami i wtedy drzwi zdają się go śledzić. Drzwi są punktem na granicy tranzytowego miejsca/nie-miejsca - wyznaczają przejście do innego świata. Przypominają znak uczyniony „przez zaostrzony przedmiot"11, przebicie w przestrzeni pokoju i przecięcie czasu²: dziurę, przez którą przedostają się zjawy. Otwarcie się drzwi jest wyczekiwane przez

7 Tamże, s. 322.

8 Tamże, s. 323.

9 R. Krynicki Organizm zbiorowy, Wydawnictwo Literackie, Kraków 1975, s. 97.

10 Tamże.

11 R. Barthes Światło obrazu..., S. 47.

12 Tamże, s. 160. 
bohatera, podobnie jak przybycie upiorów. Przebywanie w zamkniętym pokoju jest dla podmiotu doświadczeniem wykluczenia - poczuciem, że sam żyje jak widmo. Drzwi, które mają się otworzyć, hipnotyzują, wywołując śmiertelny lęk.

Jednak drzwi w tym wierszu są zamknięte. „Zjawy i wampiry” pozostają sprawą wiary. Dopiero w puencie okazuje się, że zmarli poeci nawiązują kontakt z żywymi i coś do nich mówią. Ułamkowe wyjaśnienie dotyczące tej sekretnej opowieści znajduje się w kodzie wiersza To Krynickiego, ostatnim utworze Organizmu zbiorowego, który został poświęcony pamięci Przybosia: "słowa? / rdzenie nie narodzonych zmarłych?"13. W drugiej wersji To (tytuł sugeruje punctum, to, co celuje w bohatera, uderza go, dźga, rani lub uciska) zakończenie jest już inne: „słowa? / tchnienie żywych / nienarodzonych, / zmarłych?" (s. 113). Pomimo różnicy przekaz wydaje się podobny w jednym aspekcie: żywi słyszą zmarłych poetów. Ci, którzy odeszli, zostawili jakieś strzępki czy też szczątki swoich słów, które stały się rdzeniami nowych wyrazów - odrodziły się słowa zmarłych, ale zmarli są nienarodzeni, chociaż $i$ to się zmienia. Najpierw żywi rodzą słowa zmarłych, następnie powołują martwych do życia. W drugiej, mniej zagadkowej puencie widmowe słowa/ tchnienia cyrkulują między żywymi, nienarodzonymi i nieżywymi. Właściwie są to słowa tworzące jedno tchnienie, jakby żywi i zmarli jednocześnie wdychali i wydychali powietrze, artykułując głoski. Niepewność dotycząca słów, czy raczej pochodzenia słów, wyjaśni się po odkryciu miejsca ich narodzin.

Bohater wierszy Krynickiego bezustannie przechodzi z obszaru życia w sferę śmierci, i z powrotem. Martwi wracają do życia, bo ciągną ich słowa i można je za Derridą porównać do haseł otwierających przejścia albo pośredników podczas nielegalnego przekraczania granicy bytu/niebytu.

Francuski filozof, omawiając znaczenie sekretnych słów w poezji Celana, zaznaczył, że tajemnicze szibbolety uwidaczniają się między innymi jako próg, drzwi, tablica, rzeka, nacięcie, stygmat, blizna, rana, stempel, data pod wierszem. Derrida, wielokrotnie definiując szibbolet, stwierdza, że określa on „wszelkie znamię nieznaczące, arbitralne”, lecz różnicujące i nieodzowne (jak punctum), , aby przekroczyć granicę miejsca lub próg wiersza”14. Nie sądzę, żeby celem tej wędrówki w twórczości Krynickiego była chęć zamieszkania w języku, o której pisał autor Szibboletu dla Paula Celana. Wydaje

R. Krynicki Organizm zbiorowy, s. 101.

14 J. Derrida Szibbolet dla Paula Celana, przeł. A. Dziadek, Fa-art, Bytom 2000, s. 30-31. 
się to niemożliwe ze względu na status tekstu, który jest i nie jest. Azyl jest nieosiągalny dla podmiotu poruszającego się w przestrzeni między życiem a śmiercią, lecz wszystkie zjawy mogą swobodnie rezydować w widmowych wierszach.

W takim razie jak można odczytać szibbolet „rdzenie nie narodzonych zmarłych” z pierwszej wersji To Krynickiego? Kombinacja wyrazów „rdzenie” $\mathrm{i}$ „nie narodzonych” wywołuje skojarzenie „rdzenia” z „rodzeniem” i „nierodzeniem". Mówienie jest powtórnym rodzeniem słów, które należały do zmarłych - dzięki temu ich słowa i oni mogą wieść na wpół wyraźne życie po śmierci. Nienarodzony w tym przypadku oznacza 'narodzony inaczej,' istniejący inaczej', czyli w sposób sekretny. Jedno z widm z wiersza Krynickiego Ktoś, Kaspar Hauser stanowi tu symptomatyczny przykład. Hauser, sensacja z początku XIX wieku, był tajemniczym podrzutkiem, prawdopodobnie synem księcia Badenii, podmienionym, wywiezionym i ukrytym zaraz po urodzeniu w piwnicy, gdzie dorastał. Kiedy skończył szesnaście lat, pojawił się w Norymberdze, a kilka lat później został zamordowany przez nieznanego sprawcę. Trakl nazwał Hausera „nienarodzonym”15 z powodu niewyjaśnionej zagadki jego pochodzenia i śmierci. W utworze Krynickiego Hauser jawi się jako pierwszy w sennym ciągu niedoszłych „ja” bohatera - powrócę do tego tematu, analizując złudną obecność podmiotu w twórczości autora Aktu urodzenia.

Z pewnością istnieją jeszcze inne wyjaśnienia sensu wyrażenia „rdzenie nie narodzonych zmarłych”. Być może widma są przywoływane spoza granicy wiersza, ale pewnie nigdy nie opuściły terytorium poezji, która zaczyna przypominać zbiorowy organizm składający się ze zmarłych i żywych - wskazywałby na to tytuł tomu Krynickiego: Organizm zbiorowy, skąd pochodzą analizowane utwory. Kiedy słabną funkcje życiowe tego poetyckiego organizmu, wtedy słychać odgłosy przypominające pracę respiratora, dlatego w drugiej wersji To pojawiają się słowa porównane do tchnienia.

Widma pełnią także funkcje wartowników na przejściach granicznych wiersza, dlatego niektóre słowa zmarłych wymawiane/zapisywane przez żywych mogą się zemścić, jeśli zostaną niepoprawnie użyte lub powiedziane. Derrida, szukając śladów tajnego języka w poezji Celana, przywołał historię z Księgi Sędziów: Gileadczycy pod wodzą Jeftego rozgromili Efraimitów i odcięli im dostęp do rzeki Jordan. Pokonani starali się przedostać przez

15 G. Trakl Piosenka o Kasparze Hauserze, w: tegoż Sebastian we śnie, przeł. A. Pomorski, Oficyna Literacka, Kraków 2001, s. 175. 
strzeżony bród. Gileadczycy żądali od każdego zatrzymanego człowieka, aby wypowiedział słowo „szibbolet”. Wrogowie Jeftego wymawiali je, sepleniąc, dlatego ginęlii'

Szibbolet z wiersza Krynickiego zawiera rdzenie, to znaczy najważniejsze części jakiegoś ogólniejszego znaczenia, które fragmentarycznie odsłaniają się w zetknięciu To z Mostarem Juliana Przybosia. W wierszu Przybosia świat "nie-i-jest" - ta dewiza stała się mottem Organizmu zbiorowego. W Mostarze miejscem rozważań o życiu i śmierci, czyli istocie istnienia (rdzeniu?), jest most, natomiast w utworze Krynickiego pojawiają się drzwi, które inaczej łączą rozdzielone przestrzenie. Most scala brzegi życia i śmierci, wyznaczając kierunek przejścia od jednego punktu do drugiego" ${ }^{17}$. Natomiast drzwi są membraną między żywymi i zmarłymi: w tekstach lub między tekstami pojawia się półprzepuszczalna błona, na której zatrzymują się cząstki słów należące do zmarłych. Potem posłużą żywym jako morfemy nowych wyrazów.

W poezji Krynickiego drzwi przemawiają równie tajemniczo jak zjawy. Wchodzenie/wychodzenie przez drzwi przypomina ożywianie, płodzenie lub rodzenie obumarłych słów. Jest to efektem szczególnej podwójności widzenia zasygnalizowanej wiele lat temu przez Barańczaka - osobliwość, wręcz szaleństwo tej metody polega na przyjęciu, na równych prawach, zewnętrznego i wewnętrznego punktu widzenia - perspektywy nieludzkiej i ludzkiej. Takie naznaczenie tekstu wskazuje na jego nawiedzenie, przestrzeń staje się niejednorodna, a czas wypada z zawiasów ${ }^{\mathbf{1 8}}$.

Miejsce, w którym przebywa podmiot wiersza Czasami wierzę/Wierzę, bardziej przypomina kryptę niż pokój, a może bohater znalazł się w nawiedzonym domu poezji, który odznacza się mglistą strukturą i mieszkają w nim dzicy lokatorzy, którzy straszą nowo przybyłych ${ }^{19}$.W takim razie przeświadczenie

16 Zob. J. Derrida Szibbolet..., s. 26-27.

17 Zob. G. Simmel Most i drzwi. Wybór esejów, przeł. M. Łukasiewicz, Oficyna Naukowa, Warszawa 2006, S. 252.

18 „Widma rozwarstwiają i podmywają stabilność «teraz», ujawniając anachroniczność rzeczywistości i heterogeniczność czasu: przeszłość wcale nie chce odejść, a przyszłość - nadejść" - A. Marzec Widmontologia. Teoria filozoficzna i praktyka artystyczna ponowoczesności, Wydawnictwo Bęc Zmiana, Warszawa 2015, s. 193. Badacz analizuje wywichnięcie czasu i sentencję Hamleta: "The time is out of joint" (tamże, s. 211-229).

19 A. Marzec w Widmontologii... omawia motyw nawiedzonego domu, przywołując m.in. kategorię gościnności J. Derridy (s. 133-157). 
bohatera, że istnieją istoty lub zjawiska nadprzyrodzone, jest uzasadnione, jak również fakt, że słowa rosnące w ustach „łakną jedynie naszej krwi” ( $S a$ stowa, s. 153).

Wchodzenie $\mathrm{w}$ nieistnienie $\mathrm{i}$ wychodzenie $\mathrm{z}$ istnienia to podstawowe aktywności podmiotu. Podobnie zachowują się widma. Taka sama reguła rządzi światem, okazuje się, że również i tekstem. Drzwi, jeszcze zamknięte w Czasami wierzę/Wierzę, niezarysowane w To, otwierają się, są otwierane i pozostają w ciągłym ruchu otwierania/zamykania w wielu utworach Krynickiego. Drzwi pojawiają się ponownie w cyklu Próg, drzwi i stają się przegubem $^{20}$ między przeszłością i teraźniejszością. Wtedy można dostrzec inne punctum: „próg dzieciństwa” (Jak zwykle, inaczej, s. 375), drzwi narysowane w wyobraźni («Muszę sobie tylko wyobrazić drzwi», s. 376) i nicość/coś (stuk-puk, s. 377).W pierwszym utworze tego minimalistycznego cyklu widać próg z czasów dzieciństwa. W drugim drzwi rodem z Samotności Brunona Schulza. Natomiast coś/nic to wiadomość od Mirona Białoszewskiego, przekazana bohaterowi przez sen, w którym tytułowe stuk-puk urzeczywistnia oniryczne drzwi. Te trzy elementy wyznaczają wyrazistą oś w widmowym modelu poetyckiego świata. Początkiem tej linii było punctum z wiersza Czasami wierzęl Wierze - drzwi, które „żyją własnym życiem” (s. 109). Gdy w końcu drzwi otworzyły się na oścież, życie bohatera i zawiła egzystencja widm stworzyły silny, choć na wpół jawny układ. Gra między podmiotem a zjawami toczy się dalej: życie i śmierć tracą kontury, podobnie jak człowiek i widmo, czas i przestrzeń.

\section{2. Życie w śmierci i śmierć $w$ życiu}

Paradoksalna podwójność widzenia bohatera wierszy Krynickiego zaczyna przypominać grę w otwarte drzwi i grę w dwa ognie, przywołane w wierszu *** (spróbujmy więc jeszcze raz...). Pierwsza gra polega na umiejętnym otwieraniu kolejnych drzwi, aby wyjść z wielopoziomowego labiryntu. Druga to rozgrywka, podczas której zawodnicy wykluczają przeciwników z boiska, uderzając w nich piłką.

Dwoma ogniami i dwojgiem otwartych drzwi w utworze Krynickiego są „dzieciństwa i wojny, scalające się / w popiół. Popiół dzieciństwa za nami, przed nami dwojaki płomień / nie do odczytania" (s. 27). Przedstawiona

20 G. Simmel Mostidrzwi..., s. 251. 
sytuacja odzwierciedla nieludzki stan zobrazowany w Bizancjum W.B. Yeatsa: życia-w-śmierci/śmierci-w-życiư ${ }^{21}$.

Dwojaki płomień wskazuje na intymny związek ze zmarłymi i ich słowami. Bohater zachęca siebie i innych: „czytajmy z ognia, z tej / wygasłej / linii życia, czytajmy, obumarli w sobie jak języki / przepadłych pokoleń" (s. 27). W puencie podmiot nazywa siebie „pośmiertnym dzieckiem”; czy dlatego, że jego słowa rodziły się z resztek słów zmarłych, a potem on będzie zasilał język jeszcze nienarodzonych? Ożywianie szczątkowych słów nie świadczy o przymusie powtarzania (słowo może pozostać „bezpotomne”), którego celem jest uwolnienie się od traumy lub lęku²2 (skutki wstrząsu mogą być trwałe, a poetycka trauma zwykle jest dziedziczona), lecz odsłania inny przebieg zdarzeń: strzępy wchłaniane przez podmiot dzielą się i rosną nowe słowa, które następnie są wydawane na świat. Płodzenie słów ze zmarłymi i rodzenie pogrobowców może być urazem, lecz w twórczości Krynickiego poezja od chwili debiutu przypomina powtarzający się proces narodzin, a matkami/ ojcami wielu utworów są widma. Abiektalny proces ${ }^{23}$ płodzenia/rodzenia słów, odbywający się skrycie na obrzeżach bytu/niebytu, stygmatyzuje tekst. Odtąd poezja będzie nosiła znamię widmowości.

Bohater wiersza *** (spróbujmy więc jeszcze raz...) wchodzi do krypty pamięci, w której czas staje się pustym słowem, a przestrzeń przeistacza się w podziemny labirynt zmarłych. Wydarzenia te przywodzą na myśl poetycką kryptonimię ${ }^{24}$, czyli przebieg zmian, podczas których „podmiot tworzy

21 „Przede mną płynie obraz - człowiek albo widmo, / Widmo raczej, lecz bardziej obraz niźli widmo; / Mumie, szpule Hadesu płótnem owinięte, / Mogą omotać ścieżki kręte; / Wyschłe usta zwołają, chociaż tchu brak w piersi, / Usta żywe, zdyszane; / Witaj nadludzki stanie; / Śmiercią-w-życiu nazywam cię i życiem-w-śmierci" - W.B. Yeats Bizancjum, przeł. S. Barańczak, w: J. Merrill Wybór poezji, przeł. i oprac. S. Barańczak, Wydawnictwo a5, Kraków 2001, s. 136.

Zob. A. Czabanowska-Wróbel Krynicki: poezja i powtórzenie, w: Pismo chmur. Studia i szkice o poezji Ryszarda Krynickiego, red. P. Próchniak, Wydawnictwo EMG, Kraków 2014, s. 311-327.

Nawiązuję do pojęcia z teorii ). Kristevej (Potęga obrzydzenia. Esej o wstręcie, przeł. M. Falski, Wydawnictwo Uniwersytetu Jagiellońskiego, Kraków 2007) oraz kategorii M. Douglas (Czystość i zmaza. Analiza pojęć nieczystości i tabu, przeł. M. Bucholc, PIW, Warszawa 2007). Zob. także hasło "abiekt" I. Kowalczyk, w: Encyklopedia gender. Płeć w kulturze, red. M. Rudaś-Grodzka i in., Czarna Owca, Warszawa 2014, s. 15-17.

„Nawiedzenie przez widmo czyni z podmiotu pojemnik na cudzą opowieść, która znajduje się poza jego własną świadomością, kontrolą i pochodzi z innego czasu [...]. Badania psychoanalityczne [Nicholasa Abrahama i Márii Török - przyp. I.M.] pokazały, że ludzie oraz teksty nie są jednorodne, lecz każdy z nich przeniknięty wielością niesie ze sobą widmową obecność innych. W ten sposób intymne wnętrza naszych przedmiotów oraz książek stały się zaludnione 
słowa lub tekst mający na celu ukryć, zastąpić to, co ma pozostać na zawsze tajemnicą"25, na przykład obcowanie z widmami i skalane początki poezji, lecz jednocześnie pośrednio bądź nieświadomie podmiot wskazuje na rzecz, której nie rozumie lub nie umie wyjaśnić. Szibbolety są kryptonimami, za pomocą których można otworzyć drzwi do krypty ${ }^{\mathbf{2 6}}$ przeszłości, chociaż same pozostają „szyfrem szyfru, zaszyfrowanym ujawnianiem szyfru jako takiego"27.

W wierszu Drzwi bohater wkracza w przestrzeń, w której roi się od widm:

Czcze słowo, słowo nie do wymówienia: czas. Oto

nie przypomniałeś sobie w porę tego języka i zostałeś

w cieniu drzewa

drzwi. W lesie popiołu, w puszczy popielcowej

spotkałeś przyjaciół

o oczach drzew. W drzwiach otwierających rysy

twarzy. Kobieta nocy wcieliła cię w siebie. W lesie

umarłych, w lesie martwych języków

zginął twój rękopis,

nie odnalazłeś go $[\ldots]$

(s. 55)

We wcześniejszej wersji wiersza pojawił się „rękopis twojego ciała”, ${ }^{\mathbf{2 8}}$,który pozostawał nieczytelny, podobnie jak strony książki czy świata. Czy rękopis ciała jest własnoręcznym zapisem podmiotu piszącego w/na swoim ciele, czy jeszcze inni wpisują coś w jego ciało? ${ }^{29}$ Obie te czynności mogą odbywać

i zamieszkane przez różnych, czasami również niepożądanych gości" A. Marzec, Widma, zjawy i nawiedzone teksty - hauntologia Jacques'a Derridy, w: Wymiary powrotu w literaturze, red. M. Garbacik i in., Libron, Kraków 2012, s. 257. Proces składający się z włączania i usuwania (kulturowego zjadania i wydalenia) przedmiotu/podmiotu żałoby analizował M.P. Markowski, zob. Jacques Derrida: mowa żałoby, w: Derrida / Adirred, red. D. Ulicka, Ł. Wróbel, Akademia Humanistyczna im. A. Gieysztora, Pułtusk 2006, s. 27-51.

25 A. Marzec Widmontologia..., s. 256.

26 J. Derrida Szibbolet..., s. 30.

27 Tamże, s. 31.

28 R. Krynicki Organizm zbiorowy, s. 28.

29 "Czy to nie o obrzezaniu, o tej zaszyfrowanej ranie do odszyfrowania mówi Celan w zakończeniu wiersza *** Dein vom Wachen... [...] - te wersy mówią w każdym razie o przejściu dalej, 
się na przemian i świadczą o tym, że podmiot jest autoryzowanym lub ulepszanym tekstem, poznaczonym naniesionymi poprawkami, które kojarzą się $\mathrm{z}$ ranami i bliznami. Labiryntowa przestrzeń w krypcie/lesie umarłych jest zamknięta, lecz nieskończona - przypomina świadomość i nieświadomość zaludnione przez rozliczne zjawy.

Drugie wejście w sferę zmarłych jest konwencjonalne i odsłania się w monologu nad grobem Ezry Pounda (*** [Roztargnienie? Niepamięć? Przypadek?...], s. 221) oraz w utworach poświęconych Josifowi Brodskiemu (Grób Josifa Brodskiego, s. 336-337) i Franzowi Kafce (Kasztan, s. 339). Z kolei dwa wiersze: Kolonia, daleko (s. 332) i Fragmenty z roku 1898 (s. 299) są sugestywnymi odniesieniami do poezji, życia i śmierci Celana.

Trzecie wejście w przeszłość wiedzie przez sny, w których przychodzą widma zmarłych poetów i pisarzy. W cyklu Wiersze podróżne zamieszczonym w tomie Kamień, szron, oprócz cieni Pounda, Brodskiego, Kafki, zjawiają się między innymi György Petri (Jakie tam?, s. 325), W.G. Sebald (Przebudzenie, s. 333) i Jürgen Fuchs (W Berlinie, s. 338), Zbigniew Herbert (Przelotem, s. 235; Gołębie, s. 340-341; Dotknać, s. 366), Czesław Miłosz (Silniejsze od lęku, s. 217). W twórczości Krynickiego sny bywają kryptonimami, jak motto wiersza Dziś w nocy (s. 382): „.... als ein Kranich" („... jako żuraw”), zaczerpnięte z utworu $Z a$ dnia Paula Celana. W snach wyrasta mur dziwnego labiryntu pozbawionego wejścia (Vade) ${ }^{30}$, bohater wierszy Krynickiego odbywa pośmiertne podróże za życia (Podróż pośmiertna [I], [II], [III], s. 50, 54, 93), aż w końcu staje przed przezroczystymi drzwiami: „Sny, wiersze ze szklanych drzwi: / można sobie o nie rozbić głowę / albo obudzić się po drugiej stronie" (Uwaga, drzwi!, s. 269). W utworach, które powstały w snach i są przezroczyste jak szkło, uwidaczniają się widma, choć nawet tutaj nie są całkowicie obecne. Szklane drzwi to skorelowane rozdzielenie/połączenie świata i zaświata, a w snach można przejść przez zamknięte drzwi. Rozbicie głowy grozi raczej na jawie. Teksty oniryczne (usłyszane przez sen? podyktowane przez kogoś?) są splotem sprzeczności, lecz sny od czasów Homera dzielą się na znaczące i nieznaczą$\mathrm{ce}^{31}$ - marzenie senne to pośredni stan między życiem a śmiercią, świadczący o dwupostaciowości świata, który jest i nie jest.

ponad to, co jest czytane aż do krwi, do rany, by dojść do miejsca, w którym szyfr wpisuje się boleśnie w samo ciało" - J. Derrida Szibbolet..., s. 61.

R. Krynicki Vade, „Kwartalnik Artystyczny” 2008, nr 1, s. 63-64. 


\section{Nawiedzone wiersze/nie-wiersze}

Według Derridy poezja to "nieunikniona widmowość"32 - słowa powracają i błądzą jak fantomy. Jeśli wiersze mają swoje cienie, to czego można się od nich (i o nich) dowiedzieć? W przypadku Mostaru Przybosia, który jest widmem To Krynickiego, widnieje więcej znaków zapytania niż odpowiedzi na te pytania: „Świat się zaczyna, nie spełnia? / Ani nie istnieje, ani nie nie istnieje? / Wieczna niepewność, ustawiczne Między, / to, co zowiemy Bytem - jest że?"33. Permanentne stawanie się świata, przebywanie w świecie, który jest i nie jest, to również wyznaczniki niepewnego istnienia tekstu. Stan zawieszenia między bytem a niebytem jest rozpoznawalny od razu, jeśli bohater wiersza znajduje się na moście - w Mostarze brzegi życia i śmierci są widoczne z dystansu, lecz blisko jest woda i niebo. „Wieczna niepewność" Przybosia określająca bycie została uzupełniona wątpliwościami w utworze Krynickiego - obiekcje dotyczą możności powrotu zmarłego: „Będziesz wracać, mijając własne słowa, trwonione / przez cudze wargi [...]”, „będziesz? będziesz wracać, omijać bez skargi / miejsca, gdzie przebywałeś, lecz bywałeś zamiast / kogoś, kto nie pojawi się więcej?" (s. 113).

Większość utworów Krynickiego nie ma stałych granic, różne wersje jego wierszy powstawały w ciągu lat: „tekst poetycki nie jest u niego nigdy zamknięty"34 - jest otwarty jak drzwi lub przypomina szklane drzwi. Tekst istnieje niepotwierdzony i jego status jest ciągle podważany.

W najwcześniejszym wariancie inicjalnego utworu z pierwszej publikacji Krynickiego, arkusza Pęd pogoni, pęd ucieczki, wiersz jest „nieprzemijający”, czyli „nienapisany" ${ }^{35}$. W drugiej wersji, z Aktu urodzenia, tytuł znika, a w epitecie "nie- // napisany" ${ }^{\text {"36 }}$ zjawia się dywiz i słowo dodatkowo zostaje przedzielone

„Widmowe powracanie jest udziałem [...] wszystkich słów i to już od momentu ich zaistnienia" - J. Derrida Szibbolet..., s. 60.

33 J. Przyboś Sytuacje liryczne. Wybór poezji, wyb. E. Balcerzan, A. Legeżyńska, Ossolineum, Wrocław 1989, s. 331. Drugie motto tomu Krynickiego (pierwsze z Mostaru Przybosia zniknęło w kolejnych wydaniach zbiorów wierszy) brzmi: „Gdyby oczyścić drzwi percepcji, każda rzecz jawiłaby się taka, jaka jest: nieskończona (William Blake)".

34 M. Stala Purgatorium (Na marginesie „Niepodległych nicości"), w: tegoż Chwile pewności. 20 szkiców o poezji i krytyce, Znak, Kraków 1991, s. 170.

R. Krynicki, *** (jak powstaje...), w: tegoż Akt urodzenia, Wydawnictwo Poznańskie, Poznań 1969, s. 9. 
przerzutnią. Natomiast w trzecim, znacznie zredukowanym wariancie, zamieszczanym w kolejnych zbiorach poezji, tytuł został przywrócony, lecz obcięty: jak powstaje. Nie ma wcześniejszej puenty, w której brak przemijania byłby powiązany z niezapisywaniem. Nowe zakończenie brzmi następująco: „jak / i przeciw komu, / przeciw czemu powstaje, / przeciw komu wybiega, wiersz? nadzieja? // i strach spełnienia?" (s. 7).Ufność, że coś się spełni, czyli coś zostanie zapisane, jest pełnym nadziei czekaniem na wiersz, który byłby szansą na jakąś zmianę, ale strach spełnienia (wywiązania się z obietnicy niezapisywania?) szybko przekreśla taką możliwość.

Czym jeszcze jest umotywowane radykalne odwrócenie się podmiotu od zapisanych słów? W Czasami wierzę/Wierzę bohater obracał się plecami do drzwi, za którymi stała śmierć i czaiły się widma. Unikał „wypowiadania słów, które potrafią się zemścić” (s. 109). Ale „strach spełnienia” wskazuje raczej na lęk przed urzeczywistnieniem się czegoś nieodwołalnie, co oznaczałoby zamknięcie wiersza. $\mathrm{Z}$ tego powodu w poezji pewne rzeczy mogą spełniać się wtedy, gdy niczemu nie służą (jak w wierszu Róża, tym wyrazistsza, im bardziej jest niema, s. 43). Podważenie tego, co mogłoby być utrwalone w niezmiennej wersji, nie osłabia tekstu, wręcz przeciwnie - umacnia go w spektralnym bycie. Akt otwierania (drzwi), niekończenia (wiersza) jest wzięciem w nawias decyzji lub wyrzuceniem kogoś/czegoś poza nawias bytu. Tekst podobnie jak duch może być i nie być: potwierdzać się i zaprzeczać sobie.

Przedmiot wierszy Krynickiego jest tak nieoczywisty jak obecne/nieobecne ${ }^{37}$ widmo - anuluje tradycyjny dualizm początku i końca. Dlatego nie można cofnąć się do początku ani niczego zakończyć, trzeba pójść dalej, zasugerował Derrida, na teren dyskursu „nieczystego, zagrożonego, nieprawego, zmieszanego"38. To ukryte miejsce znajduje się „poza narodzinami”", czyli przed czasem, w amorficznej przestrzeni - w poezji prawdopodobnie jest punktem na granicy miejsca i nie-miejsca „śmierciopodobnego bycia"40.

37 Nawiązuję do spektralnej analizy w: J. Derrida Prawda w malarstwie, przeł. M. Kwietniewska, słowo/obraz terytoria, Gdańsk 2003, s. 440.

38 J. Derrida Ẍ́pa / Chora, przeł. M. Gołębiewska, Wydawnictwo KR, Warszawa 1999, s. 92.

39 Tamże.

40 Fragment aforyzmu G. Trakla cytuję za: A. Kopacki Chybionym gestem. O kilku wierszach Georga Trakla, w: tegoż Muszle w kapeluszu. Szkice, rozmowy, recenzje, Biuro Literackie, Wrocław 2012, s. 37 . 
Wiersz „próbuje przebić się przez czas” i bierze „na coś kurs"41, obiera kierunek na jakieś „ty”, „,chce się przedostać do tego innego [...], potrzebuje jakiegoś vis-à-vis"42 - szuka miejsca do rozmowy w przestrzeni „, jednorazowej”“3 teraźniejszości. Według Celana poezja idzie gdzieś dalej, wyprzedza wszystko na swej drodze, zmierza do jakiegoś spotkania. Przecina peryferia milczenia, zmienia kierunek (nazywany też zmianą oddechu; może jest to tchnienie, tchnięcie w kogoś/coś życia) - zatacza koło i cykl się powtarza. Wiersze Krynickiego pozostają otwarte (od początku, czyli od narodzin) i również nie zmierzają do końca. W kontekście Celanowskiego Meridiana inaczej można odczytać pierwotne zakończenie jak powstaje: wiersz „nieprzemijający”, to znaczy „nienapisany”, jest absurdalnym wierszem absolutnym ${ }^{44}$, który krzyżując i myląc ślady, przechodzi przez bieguny początku, końca i bez ustanku kołuje ${ }^{45}$.

Nierozpoznane początki skrywają się w enigmatycznym miejscu, nazywanym przez Derridę chorą, która daje wolną przestrzeń wszystkiemu i wszystko zawiera, a może jest koniecznością, „która ani nie rodzi, ani nie jest zrodzona"46. Filozof postuluje, żeby pójść właśnie w tym kierunku, przekroczyć i podważyć platoński początek, preplatońskie pierwsze zasady i wrócić do prawdopodobnego „pra-początku" ${ }^{47}$, "początku starszego niż początek" ${ }^{\text {48 }}$.

Odwoływanie początku w poezji wygląda podobnie. Celan wyznacza południk, za pomocą którego łączy bieguny jakiegoś „ja” i jakiegoś „ty”, a w jego utworach nie ma szczelin ani przerw, „za to są różne możliwe początki”49.

41 P. Celan Przemówienie z okazji przyjmowania Nagrody Literackiej Wolnego Hanzeatyckiego Miasta Bremy, przeł. F. Przybylak, w: tegoż Utwory wybrane, przeł. S. Barańczaki in., red. R. Krynicki, Wydawnictwo Literackie, Kraków 1998, s. 317.

42 P. Celan, Meridian, przeł. F. Przybylak, w: tegoż Utwory wybrane, s. 335.

43 Tamże.

44 Tamże, s. 337.

45 Tamże, s. 340.

46 J. Derrida Xípa / Chora, s. 92.

47 Tamże.

48 Tamże, s. 93.

49 "Celan miał kiedyś powiedzieć, że w jego wierszach nie ma pęknięć, za to są różne możliwe początki. Najwyraźniej chodziło mu o to, że ten sam wiersz może się realizować spójnie i precyzyjnie na różnych płaszczyznach transpozycji" - H.-G. Gadamer Kim jestem la i kim jesteśTy?, w: tegoż Czy poeci umilknq̨?, przeł. M. Łukasiewicz, Homini, Bydgoszcz 1998, s. 139. 
W twórczości Krynickiego podmiot w dalszym ciągu błądzi „u początku” (Tak, jestem, s. 383) albo unieważnia go skreśleniem (Przekreślony początek, s. 281). Dopiero w cyklu Szron, zamieszczonym wpierw w zbiorze Magnetyczny punkt, a potem w poszerzonej, przekomponowanej i zmienionej formule w tomie Kamień, szron, pojawia się wyraźniej namagnesowane punctum naprowadzające na chorę - ten punkt jest umiejscowiony wysoko i starszy niż narodziny kosmosu.

Bohater wierszy Krynickiego nie ma stałego adresu w świecie i jego prymarnym doświadczeniem jest bycie w drodze, dlatego wiersze/nie-wiersze powstają w miejscach/nie-miejscach, które mogą kojarzyć się z chorą, snem, magnetycznym punktem, przez który prześwieca boska obecność. Niekiedy te fragmenty przestrzeni, pojawiające się od Pędu pogoni, pędu ucieczki do tomu Kamień, szron, przypominają tranzytowe lub tymczasowe nie-miejsca analizowane przez Marca Augé50 , które tworzą „samotną umowność" istniejących poza czasem i przestrzenią, pozbawionych indywidualnych cech i historycznego zakorzenienia. Czas w miejscach niczyich jest nielinearny, a wydarzenia ulegają zwielokrotnieniu. Rządzi w nich pośpiech hipernowoczesności, określający kondycję podmiotu nomadycznego ${ }^{52}$. Miejsca, które nie przystają do siebie, powstały w poezji Krynickiego na skutek krzyżowania się ścieżek ludzi i widm, dlatego te mobilne przestrzenie odzwierciedlają otwartą strukturę nie-wierszy ${ }^{53}$.

50 Zob. M. Augé Nie-miejsca. Wprowadzenie do antropologii hipernowoczesności, przeł. R. Chymkowski, PWN, Warszawa 2010, s. 53. Nie-miejsce przypomina heterotopię M. Foucaulta, który stwierdził, że "niepokój naszych czasów znacznie bardziej niż z czasem związany jest zasadniczo z przestrzenią" - w: tegoż Inne przestrzenie, przeł. A. Rejniak-Majewska, "Teksty Drugie" 2005, nr 6, s. 119. Statek jako przykład heterotopii (i heterochronii) par excellence Foucaulta zjawia się jako okręt-widmo w Pancerniku "Potiomkin” Krynickiego (s. 86).

51 Tamże, s. 64.

52 Zob. G. Deleuze, F. Guattari Kłącze, przeł. B. Banasiak „"Colloquia Communia” 1988, nr 1-3, s. 221-237; tychże Traktat o nomadologii: maszyna wojenna, przeł. B. Banasiak, "Colloquia Communia” 1988 , nr 1-3, s. 239-251. M. Stala napisał, że z formuły Przybosia "«Świat nie-i-jest» wynika zdanie «Wiersz nie-i-jest», podsumowujące sposób myślenia Krynickiego o własnych utworach" - tegoż Dziewięć ścieżek wprowadzajqcych w poetycki świat Ryszarda Krynickiego, w: Pismo chmur..., S. 11-12. 


\title{
4. Niewyraźny podmiot i wyraziste milczenie
}

Podmiot wierszy Krynickiego jest niewyraźny i heterogeniczny: podwaja się, pomnaża, czasem znika. Zwykle te przemiany łączą się z milczeniem, które jest figurą nieobecności ${ }^{54}$.

W Ktoś, Kaspar Hauser tytułowy bohater jest zbiorem różnych „ja”, a wszystkie postaci coś śnią, może nawet wymieniają się snami w podziemnych labiryntach:

\author{
Ktoś, Kaspar Hauser? \\ Już nie, ktoś jak któreś z moich innych \\ niedoszłych ja, niemy Minotaur, \\ śnił mi się, śnił mnie dzisiejszej \\ nocy \\ w swej skamieniałej wędrówce \\ przez labirynty podziemnych kolei, złóż
}

bandaży i żużla

(s. 304)

W skupisku anonimowych „ja” tylko dwie zjawy są nazwane: Kaspar Hauser i Minotaur. Ich milczenie wynika z wykluczenia i długotrwałej izolacji. Może jest również oznaką skrywania jakiegoś sekretu, może zapowiedzią fatalnej śmierci - Hauser został zasztyletowany, a człowiek-byk zasieczony.

Hybrydyczność przywołanych sobowtórów (trzecim jest Büchnerowski Lenz, wspominany przez Celana w Meridianie) jest prawdopodobnie powodem, że bohater nadal szuka „swojego wcielenia” (Jakbyś nadal szukało, s. 121). Odczuwa także lęk przed innością, nieuporządkowaniem, nieczystością, dlatego w poezji Krynickiego pojawia się motyw pokuty i kary ${ }^{55}$,

54 „Widma okazują się nieodłącznie związane z obecnością i bezpośrednio w nią wymierzone, gdyż skutecznie ją osłabiają, nawiedzają i zaburzają jej pewność. Można powiedzieć, że są jedynie jej słabym śladem, nieuchwytną resztką, powracającą z przeszłości pozostałością [...] lub nigdy nie spełnioną zapowiedzią tego, co nadchodzi [...]. Zadaniem widm jest rozsadzać nigdy niezaspokojone pragnienie i (po)żądanie obecności oraz wskazywać jej niemożliwy, wyobrażeniowy, fikcyjny status" - A. Marzec Widmontologia..., s. 177-178.

55 Ostatnio motyw ten badała A. Czabanowska-Wróbel, uwzględniając kategorie psychoanalityczne - zob. tejże Krynicki: poezja i powtórzenie, s. 311-326. Przypuszczam, że problematyka winy, kary i pokuty łączy się z motywem słowa nazywanego "grzechem pierworodnym" 
powiązany z niezmazaną winą podmiotu-poety, którego wiersz zawsze jest „niedoskonałą pokutą"56, według Georga Trakla. Jednak wydźwięk maksymy Trakla jest zbyt uniwersalny w odniesieniu do widmowej twórczości autora Aktu urodzenia, dlatego sądzę, że milczenie i poczucie winy jest efektem kontaktu ze zjawami, lecz nie oznacza oddania się w ich posiadanie, bo najczęściej po zejściu się z widmami powstają teksty, które zaabsorbowały resztki słów zmarłych. Pokuta jest podróżą przypominającą ucieczkę i pośmiertną wędrówką bohatera wierszy Krynickiego, a jej kulminacyjny punkt to zejście do piekła. Motto zaczerpnięte z Podróży do piekieł Bolesława Micińskiego: „podróż może być poszukiwaniem samego siebie, może być ucieczką przed sobą, może mieć charakter pokuty i kary"57, umieszczone w Pędzie pogoni, pędzie ucieczki, a następnie poprzedzające Akt urodzenia w kilku wyborach wierszy, wskazuje na to, że pokuta zaczęła się na początku drogi twórczej Krynickiego i jest procesem niezakończonym.

Przemilczenie w poezji Krynickiego wydaje się złożoną reakcją na widok widm. Zjawy niewiele mówią, a czasem intencjonalnie milczą i w tej ciszy kryją się rozmaite sensy: ostrzeżenie, żądanie (zachowania tajemnicy?), znudzenie, zagubienie. Wyjaśnienie znaczenia werbalnej i pozawerbalnej komunikacji widm z człowiekiem znajduje się w widmontologii, która - jako wrażliwsza odmiana nauki o możliwych bytach - uwzględnia „najsłabsze głosy oraz milczenie tych, których status ontologiczny jest co najmniej wątpliwy, niewyraźny, niejednoznaczny i nie do końca określony" ${ }^{58}$. W późniejszej twórczości Krynickiego transcendentne milczenie towarzyszy podmiotowi w czasie cofania się do punktu Wielkiego Wybuchu. Przestrzeń „miejsca bez miejsca" ${ }^{59}$ staje się niemal bezgłośna w cyklu Szron, a wiersze przeistaczają się w zagadki podniesione „do wymiaru kosmosu”60. Zjawia się bezwymiarowy punkt przypominający ciemny promień nakłuwający bezkształtną

i "owocem upadku" w wierszach Krynickiego: Pęd pogodni, pęd ucieczki, Oddal się miasto i Jak powstaje wiersz - zob. tegoż Pęd pogoni..., s. 33, 11, 10. Grzech pierworodny i upadek pierwszych ludzi zniszczył rajską relację między słowami a rzeczami.

Cyt. za: A. Kopacki Chybionym gestem..., s. 370.

57 B. Miciński Podróże do piekieł, w: tegoż Pisma. Eseje, artykuły, listy, wybór i oprac. A. Micińska, Znak, Kraków 1970, s. 43.

58 A. Marzec Widmontologia..., s. 126.

59 J. DerridaX pa/Chora, s. 55.

60 G. Colli Narodziny filozofii, przeł. S. Kasprzysiak, Oficyna Literacka, Kraków 1994, s. 68. 
mgłę ${ }^{61}$ bądź mglisty obłok, „w głębi którego opalizuje coś ukrytego” ${ }^{62}$. Prapunktem jest Nic, z którego wszystko się wywodzi - osobliwość czasoprzestrzenna wymykająca się wszelkim określeniom. W wierszu Co miało początek punkt sprzed Wybuchu utożsamiony z początkiem/końcem i milczeniem jest momentem, który „nie mieści się w żadnych // ludzkich ani nieludzkich / wymiarach" (s. 368).

\section{Przełamywanie stylu}

Marian Stala podkreślał, że odmienność wczesnych i późnych wierszy Krynickiego kryje „głębszą, choć paradoksalną całościowość twórczego zamysłu [będącego] realizacją jednego projektu, jeśli nie językowego, to antropologicznego"63. Jednak ten projekt wielokierunkowej „poezji drogi” ${ }^{64}$ nie jest całkowicie antropologiczny, gdyż w twórczości Krynickiego pojawiają się widma. Wielokształtne i zwarte dzieło powstaje nielogicznie na skutek przełamywania stylu, za którym również stoją zjawy: duchy anonimowe lub mające imiona: Peiper, Przyboś, Herbert, Celan i Sachs.

Stala wyznaczył kilka szlaków w przygranicznych miejscach poezji Krynickiego. Pierwszym jest tytuł debiutu: Pęd pogoni, pęd ucieczki, formuła kierująca

w stronę tego wszystkiego, co w języku i wyobraźni Ryszarda Krynickiego, kojarzy się z ruchem i zmianą, z byciem w drodze i podróżowaniem, z nieustannym poszukiwaniem tego, co istotne, a więc żywe, i z niechęcią do tego, co uwięzione w bezruchu, co nazbyt określone, a więc martwe. ${ }^{65}$

Ale widma pojawiające się w poezji Krynickiego są ruchliwymi postaciami i wiodą intensywne życie w wierszach. Resztki słów zmarłych poetów stają się budulcem korpusów dzieł żywych twórców. Martwota nie zawsze oznacza uwięzienie w schemacie, niekoniecznie śmierć jest bezruchem.

61 Zob. G. Scholem Mistycyzm żydowski i jego główne kierunki, przeł. I. Kania, Aletheia, Warszawa 2007, s. 243. J. Derrida analizuje pojęcie ducha powracającego jako ogień w polemice z Heideggerem, zob. tegoż O duchu. Heidegger i pytanie, przeł. B. Brzeziecka, PWN, Warszawa 2015.

62 G. Colli Filozofia ekspresji, przeł. H. Buczyńska-Garewicz, Universitas, Kraków 2005, s. 72.

63 M. Stala Purgatorium (Na marginesie «Niepodległych nicości», w: tegoż Chwile pewności. 20 szkiców o poezji i krytyce, Znak, Kraków 1991, s. 170.

64 Tamże.

65 Tegoż Dziewięć ścieżek..., s. 11. 
W tytułowym wierszu Pędu pogoni, pędu ucieczki temat paradoksalnego stanu życia/śmierci został zasygnalizowany we frazie „śmiercionośne życie i życiodajna śmierć" ${ }^{\prime 6}$. W tytułowym utworze Aktu urodzenia bohater, urodzony w transporcie (śmierci?), żyje na miejscu śmierci (s. 24). Organizm zbiorowy otwiera krótki wiersz poświęcony Peiperowi (zamieszczony też w pozycji motta na okładce), którego zakończenie brzmi następująco: „Kto wybiera śmierć - nie przestanie żyć. / Kogo śmierć wybierze - ten umrze / zaledwie" $^{\text {"67 }}$. Poezja jest porównywana do transfuzyjnej krwi i przeszczepu serca: „dawcy, choć dawno pomarli / w nagłych wypadkach - to ich krew / żyje i cudze krwiobiegi spokrewnia, / i cudze ożywia wargi"68. Ci, których organy przyjęły się w cudzych organizmach, których krew krąży we wspólnym ciele poetyckim, którzy płodzą słowa z żywymi, mogą wpływać na biorców. Język w utworze zadedykowanym Herbertowi i Panu Cogito jest nazywany „dzikim mięsem”, które „rośnie [...] / w otwartej ranie ust” - od początku w poezji Krynickiego pojawiało się coś nieludzkiego, widmowego, „co rośnie w nas / i nas przerasta" (Jezyk, to dzikie mięso, s. 75).

Większość krytyków i badaczy utrzymuje, że zmiany w twórczości Krynickiego zaczęły się od tomu Niewiele więcej (1981). Rozpoznanie jest nietrafne. Stało się to o wiele wcześniej, najprawdopodobniej jeszcze przed publikacją Pędu pogoni, pędu ucieczki, a na pewno tuż po debiucie. Pierwsza wersja wydarzeń pochodzi od poety, który powiedział:

zaczynałem od wierszy krótkich. Ślady tego można odnaleźć w Akcie urodzenia. Ślady, bo moje wczesne utwory zaginęły (co dodatkowo zbliżyło mnie do poezji Peipera). Od początku fascynowały mnie wiersze enigmatyczne, magiczne zaklęcia i gnomiczne szyfry. Teksty szczątkowe, z których przetrwało niekiedy tylko kilka słów, jedna linijka. ${ }^{69}$

Nawet jeśli uznam, że utrata juweniliów jest mitem fundującym poezję Krynickiego, to istnieją dwie książki, które należy potraktować jako debiuty z tego względu, że autor odrzucił Pęd pogoni, pęd ucieczki z powodu błędów

\footnotetext{
66 R. Krynicki Pęd pogoni..., s. 35.

67 Tegoż Organizm zbiorowy, s. 9.

68 Tamże, s. 11.

69 Bicie mojego serca (Z Ryszardem Krynickim rozmawia Dariusz Suska), "Gazeta Wyborcza”, 30.06.2003.
} 
redakcyjnych, jak stwierdził, a za swój właściwy debiut uznał Akt urodzenia, który wchłonął zmienione wiersze zamieszczone w pierwszym arkuszu poetyckim. Przełamywanie stylu jest więc wpisane jakby „przed czasem” w jego twórczość, dlatego dzieło jest jednocześnie zmienne i całościowe - od 1968 roku po dziś.

Helen Vendler w swojej koncepcji przełamywania stylu podkreśla, że „stare ciało [stylu] musi się zdematerializować, jeśli poeta wie, że powinno pojawić się nowe ${ }^{70}$. Badaczka porównuje te przełomy do aktu zniszczenia poprzedniego „ja”, rozwodu, emigracji, analizując twórczość Gerarda Manleya Hopkinsa, Seamusa Heaneya i Jorie Graham. Uwzględniam jeszcze inny czynnik tego procesu - pojawianie się i znikanie widmowych przybyszów.

Nie bez znaczenia jest to, że przełamywanie dotyczy stylu, a nie poetyki, bo styl obejmuje więcej: język, doświadczenia i środki wyrazu. Słowo „styl” pochodzi od stylusa - rylca do pisania na tabliczkach powleczonych woskiem, a szpic przypomina o punctum.

Słowo „przełamywać” jest także przemyślanym wyborem, ponieważ po pierwsze jego aspekt niedokonany wskazuje na dawno rozpoczęty i niezakończony przebieg zmian, po drugie - wskazuje na czyjś opór lub jakieś przeszkody, po trzecie - kojarzy się z uderzaniem, rozrywaniem, rozdzieraniem, znowu przypominając o sile punctum. Jeśli dodamy do niego zaimek zwrotny, wtedy „przełamywać się" wprowadza nowe konteksty. Będzie oznaczało zwalczanie własnej niechęci, lęku, niepewności, jednocześnie przypomni o tym, że „przełamywanie się" jest chęcią podzielenia się czymś z drugą osobą: to na przykład przełamanie wiersza na pół i wręczenia go komuś. Zatem jak wygląda przełamywanie stylu i przełamywanie się w widmowej poezji Krynickiego?

Wiele utworów autora Przekreślonego początku istnieje w kilku wersjach i jest to jeden z najbardziej widocznych śladów świadczących o wielokrotnym przełamywaniu stylu nawet w obrębie jednego utworu. Krynicki używa co najmniej dwóch stylów w tym samym czasie, a decydując się porzucić jeden styl na rzecz drugiego, nie działa nieodwołalnie. Jeśli przyjmiemy, że jego zagubione utwory młodzieńcze były gnomiczne, to są one przeciwieństwem wierszy z Pędu pogoni, pędu ucieczki. W Akcie urodzenia, kolejnym akcie ustanawiania metody twórczej, styl nadal ewoluuje. Niszczenie poprzedniego stylu może być chwilowe lub trwałe, lecz nigdy nie jest ostateczne, przywodząc

$70 \mathrm{H}$. Vendler The Breaking of Style: Hopkins, Heaney, Graham, Harvard University Press, Cambridge, Massachusetts-London, England, 1995, s. 1. 
na myśl teorię cyklicznych eksplozji w języku¹. System języka jest otwarty jak wiersz, na granicy między żywymi a zmarłymi zjawia się punkt, nakłucie i rozdarcie, ale może to być także punkt wielkiego lub małego, zawsze powtarzającego się wybuchu.

W twórczości Krynickiego najwyraźniejsze oznaki przełamywania stylu znajduję w Akcie urodzenia i Organizmie zbiorowym. Zmiany w tekstach odzwierciedlają nie tylko „przemiany uczuć, estetycznej percepcji albo też moralnej postawy poety"72, ujawniają też czyjąś sekretną obecność, sygnalizują jakiś sekret. Teksty są nawiedzone, to znaczy powstały w wyniku nieludzkiej czy też ponadludzkiej przemocy zjaw, które przychodzą we śnie albo na jawie, zostawiają resztki swoich słów, a niekiedy zmuszają żywych do pisania i mówienia w swoim imieniu. Dlaczego zmarli kontaktują się z żywymi, czemu wykorzystują ich, traktując jak tuby dla nagłaśniania swojego przekazu? Chyba nie mają ochoty całkiem odejść w zaświat albo żywi jeszcze ciągle ich potrzebują.

Vendler analizowała przełamywanie stylu na trzech przykładach - twórczości G.M. Hopkinsa, Seamusa Heaneya i Jorie Graham. Hopkins wynalazł rwany rytm i rozstał się dramatycznie z wczesną fazą swojej twórczości. Zmiany w wierszach Heaneya odbywały się w przestrzeni gramatyki - poeta częściej stosował w wierszach określone części mowy: rzeczowniki, czasowniki, przymiotniki lub przysłówki, a w przypadku Graham, która odeszła od aforystyczności na rzecz długich wersów, metamorfozy zachodziły na poziomie zapisu. Być może zmiana stylu bywa sposobem na przerwanie rutyny bądź przygnębienia ${ }^{73}$, lecz badaczka, porównując przełamywanie stylu do przemocy podmiotu na własnym ,ja”, poddaje jeszcze inny trop, odsyłający do widm. Przełamywanie stylu raczej nie jest aktem dobrowolnym, a w fazie formowania się nowej metody, akcentuje Vendler, poeta czuje się wypędzony $z$ dotychczasowego ciała (także z ciała liryki), to znaczy nie może dalej w nim mieszkać. Proces ten częściowo łączy się ze sprzeciwem wobec prekursorów,

71 J. Łotman opisał momenty "eksplozji znaczeniowych", które otwierają „okna w warstwie semiotycznej”; porównał warstwę semiotyczną do kosmicznej, w której krążą "odłamki rozmaitych struktur, które jednakże przechowują w sobie pamięć całości, z jakich pochodzą, i trafiając do obcych przestrzeni, mogą nagle odrodzić się" - tegoż Kultura i eksplozja, przeł. B. Żyłko, PIW, Warszawa 1999, s. 54, 55.

73 Tamże, s. 72. 
bo przełamywanie i powoływanie do życia kolejnego stylu jest momentem, w którym poeta przełamuje się i ponownie siebie tworzy ${ }^{74}$.

Bycie w drodze przypomina o niezadomowieniu się poety w języku, a także o silnym wewnętrznym przymusie zmian. Pojawiające się na tej drodze widma są zarówno poprzednikami, przewodnikami, jak i przeszkodami. Niekiedy zjawy pilnują szlaku komunikacyjnego, wtedy bohater wiersza musi wymówić hasło, żeby przejść dalej. Jeśli nie zna aktualnego szibboletu, powinien wymyślić nowy albo uciekać. Przełamywanie stylu jest zatem ważnym punctum w twórczości Krynickiego i kojarzy się z granicznym punktem przywołanym na początku - z drzwiami będącymi miejscem rozdarcia czasu i przestrzeni, przez które przenikały zjawy. Punkt przełamywania stylu jest jednak mniejszy, uczyniony przez rylec, który dziurawi wiersz, a potem drze półprzezroczystą zasłonę 75 między bytem a niebytem.

Poezja Krynickiego jest zmienna i zagadkowa: krążą w niej widmowe słowa, które zrodziły się z resztek słów zmarłych, nieokreślone zjawy błąkają się w labiryntowych wierszach, niejednorodny podmiot jest nietrwały jak teksty, milczenie skrywa jakieś sekrety, a niewyraźne granice dzielą i nie oddzielają życia od śmierci. Żaden z pięciu punktów wyznaczonych w wierszach Krynickiego nie okazał się kropką, więc wszystko wskazuje na to, że twórczość autora Przekreślonego początku jest procesualna, spektralna i ciąle wymaga nowych odczytań.

74 Tamże, s. 95. Tematyka wyzwalania się spod wpływów prekursorów była przedmiotem analizy H. Blooma, w: tegoż Lęk przed wpływem. Teoria poezji, przeł. A. Bielik-Robson, M. Szuster, Universitas, Kraków 2002.

Ruchoma zasłona pojawia się w Rozmowie w górach P. Celana: „[...] ledwie pojawi się jakiś obraz, zawisa w tkaninie, i zaraz pojawia się nić, która się przędzie i oprzędza obraz, nić z zasłony; oprzędza obraz i płodzi z nim dziecko, ni to obraz, ni to zasłonę" - tegoż Utwory wybrane..., s. 305-307. 


\section{Abstract}

\section{Iwona Misiak}

CARDINAL STEFAN WYSZYŃSKI UNIVERSITY (WARSAW)

Five Instances of Punctum in Ryszard Krynicki's Spectral Poems

Analysed through concepts from Jacques Derrida's hauntology, Mark Augé's notion of the non-place, as well as Helen Vendler's notion of the breaking of style, Ryszard Krynicki's poems reveal points where space and time are punctured/torn. Misiak presents five instances of punctum that open up transitions between being and non-being in Krynicki's work. The discussion touches on the paradoxical presence of spectres, the status of haunted poems/non-poems, the heterogenous subject, silence and the causes of breaks in style.

\section{Keywords}

spectres, poems/non-poems, non-places, point, breaking of style 